\title{
Conceptualizing the effects of transfer pricing law on transfer pricing decision making of FDI en- terprises in Vietnam
}

\author{
Hong Nhat Nguyen ${ }^{a *}$, Jacquline Tham ${ }^{\text {b }}$, Ali Khatibic and S. M. Ferdous Azam ${ }^{\text {d }}$
}

${ }^{a}$ PhD Candidate, Postgraduate Centre (PGC), Management \& Science University (MSU), Malaysia

${ }^{b}$ Doctor, Senior Lecturer of Postgraduate Centre (PGC), Management \& Science University (MSU), Malaysia

${ }^{c}$ Prof. Doctor, Senior Vice President, Postgraduate Centre (PGC), Management \& Science University (MSU), Malaysia

${ }^{d}$ Doctor, Senior Lecturer of Postgraduate Centre (PGC),Management \& Science University (MSU), Malaysia

\section{H R O N I C L E}

Article history:

Received: October 20, 2019

Received in revised format: No-

vember 18, 2019

Accepted: January 6, 2020

Available online: January 62020

Keywords:

Vietnam

Transfer Pricing Law

FDI

Transfer price

Transfer pricing decision making

\section{A B S T R A C T}

\begin{abstract}
The purpose of this paper is to understand how transfer pricing law affects transfer pricing decision making in foreign direct investment enterprises in Vietnam. The study also suggests further research on the determinants over transfer pricing decision making of these enterprises to have better solutions to deal with transfer mispricing in Vietnam. A quantitative research method involving self-administered closed ended questionnaires is extended to manage Directors/Chief Executive Officers, Tax Managers/ Directors, Chief Finance Officers or Heads of Finance from foreign direct investment enterprises in Vietnam. Findings indicate a strong probability of a relationship between transfer pricing law and the transfer pricing decision making of foreign direct investment enterprises in Vietnam. Therefore, there is a need for government to have specific law on transfer pricing. Good transfer pricing database is also expected; punishment should be reasonable; transfer pricing audit process should be stronger; transfer pricing trainings should be introduced more to the enterprises. It is believed that the implementation of suitable transfer pricing law in Vietnam will assist the government better deal with transfer pricing abuse in foreign direct investment enterprises. The findings support Vietnamese policy makers to improve the law on transfer pricing. Nevertheless, tax officials and accounting representatives can have in-depth knowledge with regard to transfer pricing decision making which the outcome of this study aspires as guidance for better understanding the aspects of transfer pricing decision making while doing business in Vietnam.
\end{abstract}

\section{Introduction}

Transfer pricing has been long an issue of a particular intention in global economy according to Lall (1973), Cazacu (2017), See (2018), Nguyen et al. (2019) and OECD (2019). As globalization broadening, foreign direct investment (FDI) enterprises start to increase their international investment and trade, transfer pricing (TP) becomes developed with varieties of methods (Agarwal, 2016). Under this context, many governments from developed and developing countries pay keen attention to have control over transfer pricing in FDI enterprises (Akpojevwa, 2014). Looking back studies conducted over the past years, the studies of TP for tax avoidance carried out by FDI enterprises have always been highlighted at relevant conferences and

* Corresponding author. Tel: +84-908850999

E-mail address: nhnhat07@gmail.com (H. N. Nguyen) 
meetings around the world, including the Summit of G8, G20 or global forums on tax issues of OECD. Transfer pricing takes special attention from senior government officials to experts, economists, managers as well as the economic institutions or business communities as researchers seem to see it as a challenge to both developing and developed countries (Borkowaki, 1997b; Thang 2015a, Thu 2018). In several developed countries, the governments have implemented several methods including tariff and non-tariff barriers to deal with these phenomena, which have brought significant results. Specifically, the G20 member countries passed the BEPS package of "base erosion and profit shifting" with 15 action plans since 2015 . The so call BEPS package aims at developing solutions to prevent and to minimize the profit shifting, tax avoidance of multinational corporations.

Located in South East Asia, Vietnam is a developing country of which the Government has increasingly considered FDI as an essential resource for national development. More than thirty years since the Law on Foreign Investment of Vietnam came into effect in 1987, FDI into Vietnam has been increasing in terms of registered capital and implemented capital. According to the statistics of Vietnam Ministry of Planning and Investment (2019), by the end of 2019, Vietnam has attracted more than 30,800 FDI projects with the total registered capital of approximately 362 billion US dollars. With their business, manufacturing and trading, politicians, economists, and bankers considered FDI as a source of growth that brings about finance, expertise, know-how, technology transfer, and also the markets. FDI enterprises also create many advantages, among which include providing jobs, improving the quality of human resources, integrating profoundly and broadly into international trade. In another aspect, besides good impacts, FDI enterprises also generate some remaining and disadvantages. Among these disadvantages is the drawback of TP abuse to avoid taxes, transferring profits to the country of origin (Hung, 2017).

Aiming at maximising profits in business, TP has been long used in multinational enterprises with cross-national related transactions, or among parent companies and their branches in different countries. With the varieties in tax systems, mainly corporate income tax, these multinational companies (MNCs) will apply different methods of pricing, technology - intellectual and resources transfer, to allocate and reallocate the profits among companies of one group. In parallel with globalization, FDI capital and resources flow can quickly go from this country to others, and TP abuse becomes develop in different types and methods. This situation can make the tax officials hard to evaluate the real business situation of the companies, whether the loss is real or they make profits but reporting of loss.

Since then, Vietnamese Governments find it hard to facilitate fair competition for different enterprises types. Getting to know the importance of preventing TP abuse activities, Vietnamese Government still face many difficulties while coping with it, especially in terms of expertise and experience to control over the TP activities in FDI enterprises. In the past years, Vietnam issues a legal framework, consisting of a legal system with legal documents from the legal principles to the detailed guidance Circular for the prevention of TP. Moreover, as many countries have urgently revised, supplemented and updated those BEPS measures to strengthen, improve the guidelines on TP in their domestic laws, the Vietnamese Government issued Decree no. 20/2017/ND-CP dated 24th Feb 2017 and Circular no 41/2017/TT-BTC dated 28th April 2017 of the Ministry of Finance on $\mathrm{TP}$ administration in order to improve the legal framework, therefore can fully and comprehensively cover tools to prevent and limit the TP activities for tax avoidance. To effectively implement this Decree, Vietnamese governmental officials, especially the tax officials, need more time, expertise and experience. Meanwhile, related issues to TP like what methods FDI enterprises often use to transfer, how TP has affected the FDI host country and the determinants over TP activities of FDI enterprises have not been studied or researched in Vietnam. What is more, TP tax punishment is currently still low for FDI enterprises to stay away from TP abuse (Kumar et al., 2013; Thanh, 2018). Under Vietnamese Law, 20\% of the tax compliance charge will be collected if the enterprises are found of mis transfer pricing. In the meantime, governments of several foreign countries seem to apply more significant penalties with the figure from $100 \%$ to $400 \%$ of the tax due. According to Thang (2015b), Singapore has no penalties frame for TP, but the frequent penalty rate is $100 \%$ to $400 \%$ of the tax due; Malaysia also has no specific regulations on the penalties in their law, but would punish $100 \%$ to $300 \%$ of tax loss in case of cheating caught; and Indonesia imposes a rate of $2 \%$ to $48 \%$ monthly of the tax due.

As TP activities in FDI enterprises in Vietnam is getting more complicated, the government records of many FDI enterprises reporting of profit loss (but still enlarge their business). Therefore, this paper is carried out to identify the factors that Transfer Pricing Law affects on TP activities of FDI enterprises in Vietnam. The research question is carried to know: What is the relationship between TP law and TP decision making in FDI enterprises in Vietnam. Correctly in this study, the authors examine the dimensions of "Documentation" and "Tax Penalties" of the TP law in Vietnam. The need for understanding whether TP law has impacts on TP decision making of FDI enterprises is critical to tighten the law for the tax authorities to deal with the TP abuse. Findings derive through this paper will provide a more precise picture of TP situation in Vietnam for better TP law in the future. In terms of academia, the study on the impact of TP law on TP decision making in FDI enterprises can be the base for other researches in approaching TP and TP abuse, under the context of complex TP activities of multinational corporations in this open economy.

Having generalized the introduction, background and significance of the study, the paper is structured with six sections. The next section reviews the related literature and outlines on TP and FDI enterprises. Section 3 provides a theoretical and empirical review relating to the research questions to be addressed. Section 4 describes the research methodology used for answering the research questions. Section 5 discusses the pilot study with reliability test. Finally, section 6 presents the main conclusions and recommendation for research in the future. 


\section{Review of Literature}

Foreign and Vietnamese researches seem to have different concepts on "transfer price" and "transfer pricing". The concept of transfer pricing was first mentioned by Coase in "The nature of the firm" in 1937. In his view, when the investors establish companies, they would have more benefits than when they create a product in the market transaction even under the the best conditions. Also according to Coase, the companies may have products/services internal-price called transfer price for accounting, this is the main activity in business and accounting. Ever since then, the terms of "transfer price" and "transfer pricing" are getting more attention from governmental officials to economists, researchers as well as enterprise managers. According to OECD (2010), when members of the MNCs carry out transactions with each other (for example purchases of goods, transfers of know-how), one member of this MNC will charge a price to another member (which can be called as "transfer price"), which will be accounted in their recordings for accounting and taxable profits, and as a result, the transfer prices used by these MNCs will have an effect on the profits amount that they report and pay tax on in different country in which they do business. Vietnamese researchers like Doan (2008) define that "transfer price" is an international term pointing out how the price is set for internal transactions among affiliated companies of one multinational company, in order words, the price that these MNCs set for their import and export activities among member companies. Transfer price in these affiliated transactions is often set higher or lower to meet the objectives of enterprises, to reduce the tax payment, and therefore can increase the profits. Setting transfer price can lead to mis transfer pricing and pose negative impacts on the socio-economic development of the host countries. The term "transfer pricing" then also has different concepts. Upon the analysis from transfer price reality of MNCs, Aranoff (2000), Horngren et al. (2003) define TP as the price set for transferring of tangible and intangible assets, goods or raw materials, or services, between responsibility divisions or departments of one company, and come to a conclusion that TP activities are not only implemented in MNCs with transnational transactions but also among related companies in the same country. Researchers and managers in Vietnam including Phan (2010) and Nguyen (2012) do not have much difference to the concepts of international researchers on "transfer pricing"; however Nguyen (2012) found out that TP is not only carried out in MNCs but also in domestic affiliated partners of Vietnam; domestic enterprises take advantage of tax incentives, they establish several member companies operating in different locations with different business lines, after that they will allocate profits among these companies to minimize the total tax payment. Other phrase needs to be understood is "transfer pricing abuse". In explanation of the General Department of Taxation of Vietnam (2017), according to the international practice, the TP abuse is explained as the deployment of price setting on goods and services transactions across countries between members of the same group that not is based on the arm's length principle in order to reduce total tax amount payable by such members all over the world. In other words, TP abuse is understood as the exploitation of price setting policies on goods and services which are transferred among related parties, not based on the market value, to minimize tax amount payable by all those affiliated parties.

Generally, there is a general view that the nature of TP decision making is to move profits from the place with high corporate income tax rate to the lower one through internal transactions among affiliated parties, to reduce the tax payment in all countries, to increase their total profits. Transfer pricing activities are the activities being carried out in relating to associated parties, including TP abuse, TP manipulation or TP abuse, leading to the tax loss of the government. Following this, what are the reason of TP decision making? When the economic relations were created and diversified, coordination between associated parties, the determination of economic benefits would go beyond the scope of each specific party. It is then considered under common benefit of an economic group or affiliated group as a whole. After all, TP seems to lead to the reasons because of benefits and profits. Akpojevwa (2014) found three reasons of TP: avoidance of financial restrictions, managing currency fluctuations, and winning host country government approval. Meanwhile, Dao (2014) suggests that enterprises have TP manipulation decision making to maximize profits, enterprises in general and MNCs in mainly will take every opportunity or method to increase their profits, even the TP abuse, price cheating, or trading activities cheating, and so on. As allocating profits through TP activities will be more challenging to be found, and even if these activities are discovered, the penalties will be complicated because each government longs to protect their enterprises for the sake of national profit. There are quite several ways to categorize TP objectives, and these objectives can be achieved or not will depend on the TP policies carried out by the MNCs. As enterprises target those objectives during TP decision making, this would lead to different impacts of TP on FDI host countries. As mentioned earlier, the act of TP aims to avoid tax, to minimize total payable tax amount by an MNCs as a whole, as a result making total tax of all related nations will be reduced. However, these activities will impose different impacts on state budget revenue of each country. As the MNCs implement tax avoidance schemes through allocating all or part of before-tax-profit from high tax rate countries to low tax rate ones, this will lead to a reduction in taxable income/payment in the former and an increase in taxable income/payment in the later. The impacts of TP activities that have been analyzed from the different point of views. Akpojevwa (2014) clarified out some effects of international TP, especially revenue reduction in tax of FDI host countries. Internal prices are often set in goods and services transferring to increase costs and thereby, reduce the profit and eventually minimize the tax liability. The governments lost massive revenue due to MNCs' transfer mispricing. The MNCs through these manipulations will kill the economy of the host country. Having similar opinions with foreign researchers, authors in Vietnam also state that there are many negative impacts of TP on host nations. In the latest research, Vietnamese General Department of Taxation (2017) has generalized three main effects of TP abuse: (1) Changing the capital structure of the host countries in investment flows, wrongly reflect the business situation of the economy, creating an untruthful economic picture. (2) May lead to an economic crisis in such tax heavens. (3) FDI host nations may face difficulties in setting macroeconomic policies and then lead to politic manipulation. 
As transfer price and transfer pricing often being mentioned in related to cross border transaction, FDI and FDI enterprises are at this moment examined in this literature review. These two phrases have long appeared in the economic field as investors of one country decide to invest in another country. In OECD's phrases, an FDI enterprise is an enterprise that locates in one country and in which an investor is from another country, directly or indirectly, from $10 \%$ of its voting authority if it is incorporated, or an equal number for an unincorporated enterprise. In Vietnam, the Investment Law (2014) defines FDI enterprises as those economic organizations that meet the conditions and shall carry out investment procedures according to regulations applicable to foreign investors that categorized into three cases: (1) Having 51\% or more of their charter capital held by a foreign investor(s), or having a majority of their general partners being foreign individuals, for partnerships; (2) Having $51 \%$ or more of their charter capital held by an economic organization; (3) Having $51 \%$ or more of their charter capital held by a foreign investor(s) and an economic organization(s). For the study of this paper, FDI enterprises in Vietnam are chosen based on the annual statistics of the Ministry of Planning and Investment (2018).

In the search for the current state of TP activities in Vietnam, there are quite a lot researches on this issue. Researcher Nguyen (2015) concluded that according to annual statistics, the cases of business loss reporting from FDI enterprises are prevalent, which behind the scenery would be an untruthful loss but true profit of FDI enterprise that Vietnamese Government has pointed out and strengthened their tax inspection and TP prevention. Tan \& Trang (2017) found out that the loss of state budget due to corporate tax loss is significant as 50\% of FDI enterprises report of profit loss. In recent research in 2017, Quang found out some Vietnamese enterprises increase the price of goods, input materials or reduce exporting price, to report of loss or profit decreasing in order to avoid tax liability. Some enterprises do TP in two ways: increasing the input cost and minimizing output price; they export products manufactured in Vietnam to a low tax rate country, later export products from that country to the U.S.A or Europe. Other enterprises increase the input cost (materials, equipment, distribution cost from the parent companies) to reduce the profit, making enterprises of low or zero profits to pay less corporate income tax. Getting to know the current situation of TP activities in Vietnam, however, the Government still showed limitations as regulation and law on tax and TP has not been completed, not up to TP activities. While many countries have promulgated the Law on TP, Vietnam has just passed the Degree of the Government, Circular of Ministry of Finance. The recent Degree no. 20/2017/NDCP of the Government which came into effect from 1st May 2017 still need time to put into practice and need to be improved. However, this is a significant effort of the Government in combatting with TP activities in Vietnam.

\section{Theoretical and Empirical Review}

The earliest theory, TP is a modelling approach. Economic theories recommend that FDI enterprises will increase overall after-tax profits by shifting revenues to low-tax and deductions to high-tax jurisdictions (Horst, 1971), and the profit maximization strategy for a monopolistic enterprise selling in two markets simultaneously in the presence of TP and how the firm reacts to a given set of tariff and tax rates. Schjelderup and Sorgard (1997) extended the monopolistic model by introducing competition in the final goods market in the host nations. Also, they developed comparative static results for enterprises facing the Cournot and Bertrand competition to examine how they set transfer prices. According to these authors, if the tax and tariff rates are absent, under the Cournot competition, the MNCs would set the transfer price below the marginal cost. Landy (2006) introduced a model which analyses the effects of varying tax/tariff rates on the TP behavior of a multinational firm which engages in the Cournot competition. The author focused on the direct regulation of the transfer price. Landy introduced three types of government policy instruments: the trade policy instrument, the profit taxes and the government regulation on the transfer price. The author proves in his model that the institution of penalty has a substantial impact on the TP behavior of a company and the optimal choice of the company in case of penalty absence is to set a transfer price above the marginal cost of production. Moreover, the author indicates that changes in the tax and tariff rates have both direct and indirect influences on the nature of competition and the degree of substitutability between the final products.

With varieties of theories on TP, there are several researchers on the effects of TP laws over TP decision making of FDI enterprises that have been studied so far, both at international and national level including Ernst and Young (2016-2017), Deloittee (2016), Thang (2015b), Lohse and Riedel (2013), and Heinemann and Janeba (2011). These researchers concluded that host countries need TP law and also need to have a national council on TP management to prevent TP abuse. According to Heinemann and Janeba (2011), in many countries, policymakers have continued concerns about the implied corporate tax base losses; therefore, the governments implemented TP documentation requirements in their national tax laws in order to improve the transparency in price setting behavior and reduce the scope for tax favorable transfer price distortions. For Lohse and Riedel (2013), they empirically assess whether these TP rules are instrumental in reducing cross border income shifting behavior; with the collected data on transfer price legislation in twenty-six European countries and linked it with panel data on MNEs in Europe. Their findings show that the activities of multinational profit shifting are significantly reduced by around $50 \%$ when the countries implement or tighten TP documentation requirements. Also, according to Lohse and Riedel (2013), TP penalties create an additional stronger impact on TP decision making. The substantial decline in tax-motivated international profit shifting activities indicates that TP laws may impose positive welfare effects despite the high administrative burden they have on enterprises and tax authorities. Thang (2015) in his research shows the findings that many countries have a specific law on TP and also have a national council on TP management to prevent TP abuse; right in the South East Asian region, some countries have promulgated Transfer Pricing Law. Another essential research result is that TP methods are also an essential determinant for FDI enterprises while carrying out their TP activities. Dao (2014) found out that with unclear set 
TP methods, a large number of not only FDI enterprises but also domestic enterprises in Vietnam have TP manipulation decision making. In another study, Deloitte (2016) surveyed with TP decision makers from 251 MNCs has shown an essential role of the TP law on the company's approach to TP activities. The survey also showed that BEPS regulation implementation seems to be the top concern of these companies. Ernst \& Young (2016-2017) in their survey with 623 TP executives in 36 jurisdictions across 17 industries, revealed that $21 \%$ of respondents said they are fully compliant to TP requirements in every country. The figure means only one fifth follows the requirements so that it may depend on the law system and requirement of the country their company base. The summary of the empirical study in relating to the relationship between TP law and TP decision making of FDI enterprises as follows:

Table 1

Empirical Review Summary

\begin{tabular}{|c|c|c|}
\hline Author & Methods & Key Findings \\
\hline $\begin{array}{l}\text { Heinemann and } \\
\text { Janeba (2011) }\end{array}$ & Qualitative method & $\begin{array}{l}\text { In many countries, policy makers have increasingly paid special attention on } \\
\text { the implied corporate tax base losses. They then implemented TP documen- } \\
\text { tation requirements in their own national tax laws in the purpose of increas- } \\
\text { ing transparency in price setting behavior and reducing the scope for tax fa- } \\
\text { vorable transfer price distortions. }\end{array}$ \\
\hline $\begin{array}{l}\text { Lohse \& Riedel } \\
\text { (2013) }\end{array}$ & Quantitative method & $\begin{array}{l}\text { Specific TP penalties pose an additional stronger effect on TP decision mak- } \\
\text { ing. Multinational profit shifting activities are reduced when countries apply } \\
\text { or tighten transfer price documentation requirements. }\end{array}$ \\
\hline Dao (2014) & $\begin{array}{l}\text { Quantitative re- } \\
\text { search }\end{array}$ & $\begin{array}{l}\text { With unclear TP methods, there are a number of FDI and domestic enter- } \\
\text { prises have TP violation decision making. Since the implementation of spe- } \\
\text { cific TP methods, the situation of TP abuse in Vietnam is improved. }\end{array}$ \\
\hline Thang (2015) & Case study method & $\begin{array}{l}\text { It's necessary for the host countries to have TP law and a national council on } \\
\text { TP management to prevent TP manipulation. }\end{array}$ \\
\hline Deloitte (2016) & $\begin{array}{l}\text { Qualitative method, } \\
\text { Quantitative method }\end{array}$ & $\begin{array}{l}\text { Top determinants affecting TP activities of enterprises: (1) BEPS/OECD reg- } \\
\text { ulation or how authorities respond to changes; ( } 2 \text { ) Law in general; ( } 3 \text { ) Ag- } \\
\text { gressiveness of tax authorities; (4) Country-by-country reporting require- } \\
\text { ments; and (5) Changes demanded by audits. }\end{array}$ \\
\hline $\begin{array}{l}\text { Ernst \& Young } \\
(2016-2017)\end{array}$ & Quantitative method & $\begin{array}{l}21 \% \text { of respondents agreed that they fully compliant to TP requirements in } \\
\text { every countriy. }\end{array}$ \\
\hline
\end{tabular}

\section{Research Methodology}

The author applied the research onion provided by Saunders et al. (2016) to do this research. The research onion here is a bounded framework with six layers: research philosophies; research approaches; research strategies; research methods; the time to carry out the research and academic study; and the process of data collection and data analysis to achieve key findings. Based on the literature review, the author develops the Hypotheses: (1) There is a relationship between TP law and TP decision making and (2) There is a relationship between transfer pricing decision making and FDI enterprises in Vietnam. It is presented in Fig. 1 as follows:

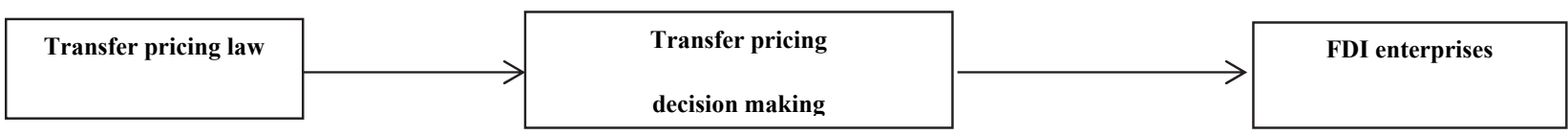

H1

Independent variable
Mediating variable

Fig. 1. Hypotheses
$\mathrm{H} 2$

Dependent variable

Approaching the first layer, the author has a choice among research philosophies. According to Li (2015), research philosophy is the development of knowledge and the nature of knowledge that researchers will acquire in specific research fields. As mentioned earlier, the four main research philosophies positivism, constructionism, critical realism, and pragmatism (Sekaran \& Bougie, 2013). In this study, positivism is acquired by researcher because this research philosophy is often used in order to express the relationship between dependent and independent variables. The researcher's plan is to collect the primary data from significant sample size, which is supported by positivism philosophy. The second layer of research opinion relates to research approach, which includes deductive and inductive, according to Saunders et al. (2016). To study this paper, the author has selected deductive approach due to several reasons. The paper is to do research on the activity behavior of Vietnamese FDI enterprises and there are a large number of empirical evidences that relate to this study's topic. In the context of TP activities, deductive approach is more appropriate to be applied as Armat et al. (2018) affirmed that deductive approach is better used when some views or previous findings and theories are available for target social phenomenon. Another important reason to choose this research approach is because deductive is suitable to positivism philosophy (Bilau et al., 2018), with large sample size (Saunders et al., 2016). 
As turning to the third layer of research strategy, which helps researcher gain a particular goal and to meet the research objective(s), the choice among research strategies will depend on the objective(s) of the research, the type of research questions, or the view-point of researcher, and on practical aspects of time constraints and data sources. Sekaran and Bougie (2013) suggested several types of research strategies as follows: experiments, ethnography, surveys, case studies, action research, and grounded theory. Since the analysis, survey is selected for this research because of several reasons. The first reason to choose this research strategy is that it often goes with deductive approach (Saunders et al., 2016) to collect the data to verify the hypothesis of this study. Secondly, this research strategy helps the author analyze the activities behavior of FDI enterprises towards TP decision making. Also, according to Saunders et al. (2016) survey strategy is often lower cost and shorter time in comparison to the others, which is last but not least reason of choosing this research strategy.

Forth layer of research onion relates to research methods. Yet research methods of quantitative or qualitative have been clearly explained by Saunders et al. (2016). Depending on the procedure of data analysis and techniques of data collection. Since quantitative research method is used with the data under numeric format and statistical analyses are used to generate findings (Saunders et al., 2016). with the straightforward to what and how question type (Biggam, 2018), this research method has been applied in this study. Moreover, as the researchers who apply quantitative method often have concerns about the measurements (Biggam, 2018) of each variable, and the evaluation of causal linkages among variables are, which is most suitable in this paper. Finally, this paper is cross-sectional (fifth layer) and so that it is better resolved by quantitative method, according to Saunders et al. (2016) and Easterby-Smith et al. (2018). The final layer concerns methods of primary and secondary data collection, which has a significant role in academic studies because it supports data analysis to obtain the key findings of the paper. Here for this study, secondary data is collected from published statistics and official reports in Vietnam and worldwide that relate to the issue. And given to the understandings of primary data, the author decides to collect data from questionnaires with the respondents - which is a useful data collection instrument in case of quantitative research is applied (Walliman, 2017) and Tham et al. (2019). According to Hanlon and Larget (2011), the population of this paper refers to the FDI enterprises locating in Vietnam that having controlled transactions with its affiliated partners. The author also collects this information in the questionnaire and in case the enterprise not meet these criteria, it will be deleted from the dataset. Expected respondents of these enterprises will be Chief Executive Officers or Managing Directors, Tax Managers, Tax Directors, Chief Finance Officers, Heads of Finance or at an equivalent position from the enterprises. Yet by the end of 2018, Vietnam has attracted 27,300 FDI enterprises (Ministry of Planning and Investment, 2018). Approaching this population, two different sampling techniques of probability sampling and nonprobability sampling are examined, which finally selecting probability sample for the study. The main reason is that type of sampling technique helps the researcher control sampling biases and systematic errors. The main sub-technique of probability sampling that is applied in this study is systematic sampling with the benefit of very easy to conduct, less cost and convenient in case of large population (Etikan and Bala, 2017). Having the technique for sampling, with the above population, two sample sizes are generated accordingly. The first sample size is decided for pilot test of the survey and the second one is chosen for official survey. The sample size for pilot test of the survey is generally from 25 to 100 or it consumes $10 \%$ of sample size of official survey (Memon et al., 2017). In addition, the researcher targets at the sample size of 379 respondents, a good number according to Krejcie and Morgan (1970) and Cohen (1969). However, in order to collect enough 379 respondents, 500 questionnaires will be delivered, in case any receivers may not answer the survey, then the remaining still qualified for data analysis. Since primary data is collected by a questionnaire, how the questionnaire is developed and implemented will be examined in this part. To solve this issue, the researcher decides to use email survey with self-administered questionnaires. The motivation of using email survey is that corporate internet usage rate in Vietnam is $100 \%$ of total population, closed format questionnaire is applied because it is clear and candid for the receivers to respond (Dillman et al., 2014) and suitable with quantitative research method (Saunders et al., 2016) as it helps the author control the quality of data collected to fulfill the objective of the paper. For the questionnaires, each item is evaluated with a specific scale of five-point Likert scale (Wadgave \& Khairnar, 2016) to collect the attitudes of the respondents. The transfer pricing law is measured with 4 items. Transfer pricing activities has 3 measurement items and FDI enterprise has 3 measurement items. The research questions are self-deployed, some of them are taken from Deloitte (2016) and Ernst \& Young (20162017). The questionnaire is displaced in Table 2 as follows:

Table 2

Questionnaires

\begin{tabular}{|c|c|c|c|c|c|}
\hline \multicolumn{6}{|l|}{ Transfer pricing law } \\
\hline 1. TP regulations of Viet Nam is strong enough to deal with TP abuse & 1 & 2 & 3 & 4 & 5 \\
\hline 2. Viet Nam Government should have specific law on TP & 1 & 2 & 3 & 4 & 5 \\
\hline 3. TP punishment in Viet Nam is strong enough to deal with TP abuse & 1 & 2 & 3 & 4 & 5 \\
\hline 4. Vietnamese TP regulations can affect the way the company making decision on TP & 1 & 2 & 3 & 4 & 5 \\
\hline \multicolumn{6}{|l|}{ Transfer Pricing decision making } \\
\hline 1. Transfer pricing decision making are often set by the parent company & 1 & 2 & 3 & 4 & 5 \\
\hline 2. The company decides transfer pricing activities along with strategic decisions like to expand the busi- & 1 & 2 & 3 & 4 & 5 \\
\hline 3. Reducing cost is among targets of transfer pricing decision making & 1 & 2 & 3 & 4 & 5 \\
\hline \multicolumn{6}{|l|}{ FDI enterprises } \\
\hline 1. TP decision making among related parties of FDI enterprise can increase global consistency of approach & 1 & 2 & 3 & 4 & 5 \\
\hline 2. FDI enterprises always follow TP requirement of the local government & 1 & 2 & 3 & 4 & 5 \\
\hline 3. TP activities among associated partners is a method that FDI enterprises uses to operate its business. & 1 & 2 & 3 & 4 & 5 \\
\hline
\end{tabular}


After designing the questionnaire, the authors implement a pilot test of the survey. In this study, a pilot test of the survey is implemented with the participation of adequate volunteers to validate the scale of items that is prepared before. Moreover, feedbacks of the volunteers on the questionnaire's contents help the researcher modify if necessary. Finishing the pilot test, researcher then turns into the process of official survey. When giving self-administered questionnaire to expected respondents, for the official survey to collect primary data, as mentioned before, the authors utilize a web-based tool of email survey and Survey Monkey is used because it is user-friendly and online features support logical order that can help respondents easily fulfill the questionnaire. Moreover, Survey Monkey allows the researcher to give the guidance so that the respondents can follow an answer each questionnaire's item. After collecting the answers from respondents, since the research relates to the relationships between many variables, multivariate statistical techniques are required according to Sekaran and Bougie (2013). Since this paper is examined with quantitative research method and the data collection is from numeric questionnaire survey process, the researchers adopt two main techniques of data analysis: Statistical Package for the Social Sciences (the software owned by IBM with version SPSS 16.0) and AMOS. Yet SPSS is popular for apply in statistical analysis in social science papers and it is also accepted by the researchers in different areas such as government, healthcare, education, etc. (Jatnika, 2015). Meanwhile, AMOS is an adding to SPSS software, which is particularly used for Structural Equation Modeling, path analysis, and confirmatory factor analysis. It is also often used for causal modeling software with visual program for structural equation modeling (SEM). In AMOS, the researcher can draw models graphically and quickly performs the computations for SEM and gains the results.

With the above chosen research methodology components, the researchers recognize several limitations of the study. Firstly, the paper findings are based on a limited sample size. Even the sample size is acceptable for academic studies provided by previous researchers, the authors are aware of expected findings may be correct for this sample only and may not be correct for the whole population. Secondly, the limitation may come from the chosen self-administered questionnaire as this kind of survey's weakness is that the answers of the respondents are not verified and the respondents may provide the feedback that do not reflect their true thinking. Finally, the authors recognize that the choice of quantitative research method may not be able to help getting in-depth understandings about social phenomenon in comparison to the method of qualitative research. Finally, ethical considerations are also at concerns of the author while carrying out survey involving the participation of respondents according to Saunders et al. (2016). Regarding the personal information of the volunteers and the respondents, the authors guaranteed that their privacy was protected and would not be disclosed under any context. Besides, with the selfadministered questionnaire format, the anonymity to the respondents was assured accordingly. Furthermore, the authors confirm not to let the research own opinion to affect the answers of the volunteers in the pilot survey and of the respondents in the official survey. And last but not least, data collection and data analysis results are based on actual outputs with definitely no interfering into the data sources. References to previous studies are strictly followed the academic rules with no plagiarism faults commitments. All the information that is collected from questionnaire survey is archived in the author's personal computer and carefully protected by a password. It is also assured that information collected is used for academic purposes of this study only, not for any commercial purposes.

\section{Empirical Analysis}

150 respondents have feedbacked with the questionnaires. The researcher applies SPSS software to analyze: descriptive statistics, reliability test, and exploratory factor analysis. AMOS software is then used to analyze the research model and hypothesis testing.

\subsection{Demographic of the enterprises}

The demographic figures of FDI enterprises are shown in Fig. 2. These include the operation time, business field, and the department in charge of TP of the enterprises. It also includes whether the enterprise has an internal TP policy or not.

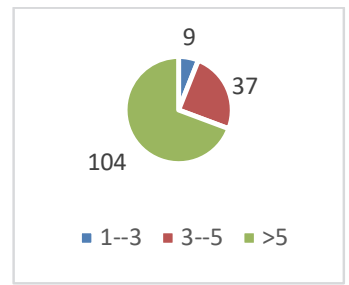

Enterprise Operation Time

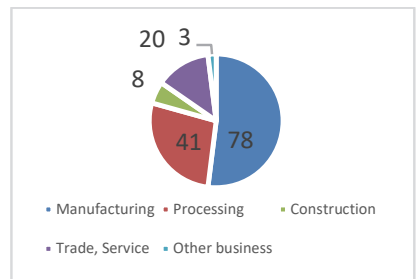

Enterprise's business field

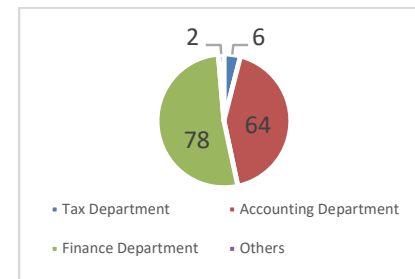

Department in charge of TP

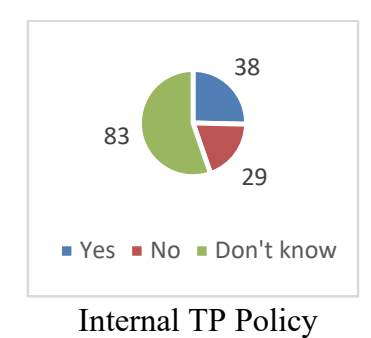

Internal TP Policy

Fig. 2. Demographic figure of FDI enterprises

The operation time of enterprises is divided into less than 1 year, from 1 to less than 3 years, from 3 to less than 5 years and from 5 years. The Survey indicates that most of the enterprises operate from 5 years (104 respondents, $69.3 \%$ ), followed by from 3 to less than 5 years (37 respondents, 24.7\%). The number of enterprises that operate from 1 to less than 3 years is 9 , accounted for $6 \%$. And no enterprise $(0 \%)$ is recorded to operating less than 1 year. 
Getting to know the business field of the enterprise, most of the enterprises are in manufacturing with 78 respondents, $52 \%$. Secondly, $27.4 \%$ of respondents (41 enterprises) informed they are in processing. 20 enterprises (13.3\%) are in trade, service; 8 enterprises are in construction and the remaining of 3 respondents $(2 \%)$ are from other business field. For the department in charge of TP activities of the enterprises, 78 respondents $(52 \%)$ confirmed it is the responsibility of Finance Department. Meanwhile, 64 respondents (42.7\%) said it is the Accounting Department. 6 respondents (4\%) said it belongs to the Tax Department and only 2 respondents $(1.3 \%)$ said it is another department to in charge of TP.

\subsection{Descriptive statistics}

Descriptive statistics express the mean value of each item in the questionnaire. The result obtained from the survey is showed in Table 3:

Table 3

Descriptive statistics

\begin{tabular}{lccccc}
\hline Item & Minimum & Maximum & Mean & Std. Deviation & $\mathrm{N}$ \\
\hline TPL1 & 3 & 5 & 3.48 & 0.527 & 150 \\
TPL2 & 2 & 5 & 3.70 & 0.515 & 150 \\
TPL3 & 3 & 5 & 3.71 & 0.509 & 150 \\
TPL4 & 3 & 5 & 3.90 & 0.343 & 150 \\
FDI1 & 1 & 5 & 3.92 & 0.629 & 150 \\
FDI2 & 2 & 5 & 3.90 & 0.610 & 150 \\
FDI3 & 1 & 5 & 4.04 & 0.684 & 150 \\
TP1 & 1 & 5 & 3.46 & 0.551 & 150 \\
TP2 & 1 & 5 & 3.26 & 0.923 & 150 \\
TP3 & 1 & 5 & 3.33 & 0.886 & 150 \\
\hline
\end{tabular}

In terms of Transfer pricing law, it includes 4 items being coded into from TPL1 to TPL4. Mean values of TPL1, TPL2, TPL3, and TPL4 are 3.48, 3.70, 3.71 and 3.9 respectively. It is emphasized that three items of TPL2, TPL3, and TPL4 have mean value more than 3.5 and TPL1 has mean value less than 3.5 and higher than 2.5. So it is concluded that the respondents agree with the statement that: Viet Nam Government should have specific law on TP; TP punishment in Viet Nam is strong enough to deal with TP abuse; and Vietnamese TP regulations can affect the way the company making decision on TP. Otherwise, they are neither agreeing nor disagreeing with the statements that TP regulations of Viet Nam is strong enough to deal with TP abuse. For FDI enterprises, the author coded into FDI1, FDI2, and FDI3. The mean values of FDI1, FDI2, and FDI3 are 3.92, 3.9 and 4.04 respectively. This figure shows that the respondents agree with all the statement items of this variable. The respondents agree that transfer pricing decision making are often set by the parent company; the company decides transfer pricing activities along with strategic decisions like to expand the business, enlarge their investment, and so on; and reducing cost is among targets of transfer pricing decision making. For the transfer pricing activities, the author coded into TP1, TP2, and TP3. The mean values of TP1, TP2, and TP3 are 3.46, 3.26 and 3.33. All the items have mean value less than 3.5 and higher than 2.5. So it is concluded that they are neither agreeing nor disagreeing with all the statements of this variable: TP decision making among related parties of FDI enterprise can increase global consistency of approach; FDI enterprises always follow TP requirement of the local government; and TP activities among associated partners is a method that FDI enterprises uses to operate its business.

\subsection{Reliability test analysis}

The authors have carried out reliability test to the check the internal consistency among items of one variable. Cronbach's alpha, Corrected item-total correlation, and Cronbach's alpha if item deleted have been calculated. Cronbach's alpha has been used to test of the inter-item consistency, according to Sekaran and Bougie (2013), Cronbach's Alpha is utilized to know the average intercorrelation among the items used to measure the concepts. The closer Cronbach's Alpha is to 1, the higher the internal consistency reliability, the range of 0.70 is considered to be acceptable, if the figure is 0.80 that will be good and excellent for 0.90 . On the other hand, if the range is low under 0.60 , the variable will be considered not good for the study and should find the item that effects the measurement, to see whether should remove it to improve the inter-item consistency. In addition, when deleting one item, the new Cronbach's alpha must be smaller than the original value before this item is deleted. The result is presented in Table 4.

Cronbach's alpha values for transfer pricing law, foreign direct investment enterprises and transfer pricing decision making have been calculated at $0.821,0.872$ and 0.776 respectively and all the figures are higher than 0.70 . The corrected item-total correlation of the reliability test shows that all items have the value of more than 0.30 . The last figure, when one item is deleted, the new Cronbach alpha is lower than the original one. Therefore, it can be concluded that internal consistency among items of a factor is satisfied. Furthermore, none of the input is deleted because the reliability test is accepted. The author then continues to EFA analysis to get the result of the survey. 
Table 4

Reliability test analysis

\begin{tabular}{cccc}
\hline Factor & Code & Cronbach's Alpha & $\begin{array}{c}\text { Corrected Item-Total Correla- } \\
\text { tion }\end{array}$ \\
& & & .562 \\
& TPL1 & 0.821 & .824 \\
Transfer pricing law & TPL2 & & .818 \\
& TPL3 & & .420 \\
\hline TPL4 & & .681 \\
\hline Foreign Direct Investment En- & FDI1 & .803 & .684 \\
terprises & FDI2 & 0.872 & .810 \\
\hline Transfer Pricing Decision & FDI3 & & .661 \\
Making & TP1 & & .315 \\
\hline & TP2 & 0.776 & .816 \\
\hline
\end{tabular}

\subsection{EFA Analysis}

EFA Analysis is required to calculate KMO and Bartlett's test. The components of initial eigenvalues of more than 1.0 are accepted and selected components must have cumulative \% variance of more than $50 \%$. Factor loading of each item is expected to be higher than 0.5 and Varimax is used as a rotation technique. The EFA analysis is conducted and the result is presented in Table 5 as follows:

Table 5

EFA Analysis result after Varimax rotation

\begin{tabular}{|c|c|c|c|c|}
\hline \multicolumn{4}{|c|}{$\mathrm{KMO}=.698 ;$ Bartlett's test $=894.392, \mathrm{p}$-value $<0.001$} & \multirow{4}{*}{ Communalities } \\
\hline Component & 1 & 2 & 3 & \\
\hline Initial eigenvalues & 2.984 & 2.720 & 1.670 & \\
\hline$\%$ of variance & 29.842 & 27.201 & 16.699 & \\
\hline TPL1 & 0.687 & & & 0.601 \\
\hline TPL2 & 0.921 & & & 0.874 \\
\hline TPL3 & 0.907 & & & 0.851 \\
\hline TPL4 & 0.665 & & & 0.540 \\
\hline FDI1 & & 0.907 & & 0.839 \\
\hline FDI2 & & 0.915 & & 0.852 \\
\hline FDI3 & & 0.820 & & 0.674 \\
\hline TP1 & & & 0.602 & 0.407 \\
\hline TP2 & & & 0.892 & 0.866 \\
\hline TP3 & & & 0.876 & 0.870 \\
\hline
\end{tabular}

The obtained findings from KMO and Bartlett's test confirm that EFA is able to use for the data set of 150 respondents. KMO value is 0.698 and it is higher than 0.5. At the meantime, Bartlett's test value is estimated at 894.392 and p-value less than 0.001. The result means that KMO and Bartlett's test satisfy the pre-test of EFA and the data analysis technique is suitable. There are three components which are extracted with initial eigenvalues of more than 1.0 and the cumulative \% variance explained by these components is higher than $50 \%$. Component 1 has an initial eigenvalue of 2.984 and it can be used to explain for $29.842 \%$ of variance. Component 1 includes all items of transfer pricing law. The initial eigenvalue of component 2 is 2.720 and it can be used to explain for $27.201 \%$ of variance. Component 2 includes all items of the foreign direct investment enterprises. Component 3 has an initial eigenvalue of 1.670 and it can be used to explain for $16.699 \%$ of variance. Component 3 includes all items of transfer pricing activities. The detail description of each component is shown further as follows:

- Component 1 includes all items of transfer pricing law and factor loading values calculated for TPL1, TPL2, TPL3, and TPL4 are $0.678,0.921,0.907$ and 0.665 respectively. All factor loading values are higher than 0.5 .

- Component 2 includes all items of the capacity of foreign direct investment enterprises and factor loading values calculated for FDI1, FDI2, FDI3 are $0.907,0.915$ and 0.820 respectively. All factor loading values are higher than 0.5 .

- Component 3 includes all items of transfer pricing activities and factor loading values calculated for TP1, TP2 and TP3 are $0.602,0.892$ and 0.876 respectively. All factor loading values are higher than 0.5 .

\subsection{Evaluation of research model}

AMOS has been used to evaluate the research model. The outputs of the model fit are presented in Table 6. It is significant that Chi-square/df (CMIN/DF) is 1.749 and it is lower than 5. CFI value is calculated at 0.973 and RMSEA is 0.071 , all are in accordance with the benchmark. It can be concluded that the model is fit with the dataset. Therefore, hypothesis testing will be analyzed in the next section. 
Table 6

Research Model

\begin{tabular}{lll}
\hline Indicator & Benchmark & Result \\
\hline Chi-square/df & $<=5$ & 1.749 \\
CFI & $>0.9$ & 0.973 \\
RMSEA & $<=0.08$ & 0.071 \\
\hline
\end{tabular}

\subsection{Hypothesis testing}

The result of hypothesis testing is presented in Table 7 below:

Table 7

Hypothesis testing

\begin{tabular}{lcccccc}
\hline & Estimate & S.E. & C.R. & P-value & Hypothesis & Result \\
\hline TP $\leftarrow$ TPL & 0.157 & 0.620 & 2.539 & 0.011 & H1 & Not supported \\
FDI $\leftarrow$ TP & 1.063 & 0.386 & 2.751 & 0.006 & H2 & Supported \\
\hline
\end{tabular}

$\mathrm{H} 1$ indicates that the transfer pricing law does not have any effect on transfer pricing decision making. The coefficient is estimated at 0.157 , not justified the benchmark of more than 0.2 . The p-value is 0.011 , yet it is less than 0.05 . Therefore, H1 is not supported.

$\mathrm{H} 2$ indicates that as transfer pricing decision making have positively and significantly on the FDI enterprises. The coefficient is estimated at 1.063 , higher than 0.2 . The p-value is 0.006 , means it is less than 0.05 . Therefore, $\mathrm{H} 2$ is accepted.

\section{Discussion and empirical results}

The obtained empirical results are different from the previous studies and programs, not support the conceptual framework that the authors have proposed. In this study, the transfer pricing law is found to have no relationship with transfer pricing decision making, but then have positively and significantly affect the foreign direct investment enterprises. Fig. 3 below illustrates the relationship between factors and items after SEM is conducted:

\begin{tabular}{|c|c|c|c|c|}
\hline \multirow{2}{*}{ Transfer pricing law } & & Transfer pricing activities & & Foreign direct investment enterprises \\
\hline & 0.157 & & 1.063 & \\
\hline
\end{tabular}

Fig. 2. Model estimation result

\section{Conclusions and Recommendations}

Transfer pricing has been getting its attention in many areas especially in the field of tax and economics as enterprises expand its businesses across countries, where the gap in tax rates may arise. To partly contribute to better understanding of TP, the research has aimed to identify the relationship between TP law and TP decision making of FDI enterprises in Vietnam. The paper has given several previous researches on "transfer pricing", different concepts of "transfer price", "transfer pricing" in affiliated companies; "foreign direct investment" and "foreign direct investment enterprises". Researchers have found out that foreign and Vietnamese researchers had different concepts on transfer price and TP. In general, transfer price is the prices that are used for the purchasing and selling of goods and services between subsidiaries or divisions within a group of companies. Transfer pricing can be understood as the deployment of pricing policy on goods and services transacted across the border between members of the same group not based on the arm's length principle in order to minimize total tax amount payable by such members over the world. Theoretical and empirical review have been made in related to the issues, and finally, from the literature review, research gap has been mentioned, out of which the author sees the need to continue study on TP, supplement and renew theory to catch up with globalization in current context of TP management and control. Research methodology is examined in session four. Research onion is, and it requires the choices of research philosophy, research approach, research strategy, research method, time horizon, and data collection. After the discussions, the researcher applies positivism research philosophy and deductive research approach. Moreover, the survey is chosen as a research strategy and primary data, therefore, is collected from a self-administered questionnaire. The researcher relies on Survey Monkey which is known as an online survey tool to implement the survey. Secondary data is also collected from published statistics and reports, and the role of this data is visible in literature. 150 respondents from FDI enterprises in Vietnam have given the feedback on questionnaires. Empirical result shows that the transfer pricing law have no relationship with transfer pricing decision making, but then have positively and significantly effect on the foreign direct investment enterprises. The author finds acceptable internal consistency reliability of the research, model testing, EFA analysis and hypothesis testing not accepted with Hypothesis 1, accepted with Hypothesis 2, which is very different to literature review. Therefore, the author suggests further research on the relationship between the transfer pricing law and transfer pricing decision making of FDI enterprises in Vietnam to be conducted with the official survey of 379 respondents as suggested in Methodology. With the above empirical analysis, the author recognizes the 
limitation of the study as the findings may be correct only for the sample, not for the whole population. However, further research in terms of the effect that TP law poses on TP decision making of FDI enterprises can be carried out upon this conceptual study framework. As FDI enterprises continue to increase in Vietnam, TP activities are more and more complicated, Vietnam has promulgated Decree no. 20/2017/ND-CP of the Government, effectively from the 1st of May 2017 with specific direction and regulations for TP. The further research to see the relationship between TP law and the TP decision making in FDI enterprises, together with recommendations for better law on TP can help much in suggesting a better solution to TP abuse.

\section{References}

Agarwal, S. (2016). Transfer Pricing Meaning Examples Risks Benefits. Available at: https://www.linkedin.com/pulse/transfer-pricing-meaning-examples-risks-benefits-shivangi-agarwal (accessed 10 Aug 2018)

Akpojevwa, O. A. (2014). The effects of international transfer pricing on host nations: An overview of developing nations. SCSR Journal of Business and Entrepreneurship (SCSR-JBE), 1(1), 34 - 41

Aranoff, G. (2000). Transfer pricing with technology choice and demand fluctuations in a simple manufacturing model. Quarterly Journal of Business and Economics, 39, 3-17.

Armat, M., Assarroudi, A., Rad, M., Sharifi, H., \& Heydari, A. (2018). Inductive and deductive: Ambiguous labels in qualitative content analysis. The Qualitative Report, 23(1), 219-221.

Biggam, J. (2018). Succeeding with Your Master's Dissertation. $4^{\text {th }}$ ed., Open University Press, UK.

Bilau, A., Emlyn, W. \& Irene, L. (2018). Research methodology for the development of a framework for managing postdisaster housing reconstruction. Procedia Engineering, 212, 598-605.

Cazacu, A. L. (2015). An approach on links between transfer pricing and tax havens. Annals of the University of Petroşani. Economics, 15, 51-58.

Cohen, J. (1969). Statistical power analysis for the behavioral sciences. CA: Academic Press, San Diego.

Dao, P.Q. (2014). Transfer pricing abuse from the perspective of enterprises. Available at http://tapchitaichinh.vn/nghiencuu--trao-doi/trao-doi-binh-luan/chuyen-gia-duoi-goc-nhin-cua-doanh-nghiep-88375.html (accessed 10 Feb 2019)

Deloitte, (2016). Trends in Transfer Pricing. Available at: https://www2.deloitte.com/content/dam/Deloitte/global/Documents/Tax/dttl-tax-transfer-pricing-global-research-bulletin.pdf (accessed 28 Dec 2018).

Dillman, D. A., Smyth, J. D., \& Christian, L. M. (2014). Internet, phone, mail, and mixed-mode surveys: the tailored design method. John Wiley \& Sons.

Doan, V.T. (2008). Methods to evaluate technology and transfer price insides multinational companies. Science and Technology Publishing, $\mathrm{Ha}$ Noi.

Easterby-Smith, M., Thorpe, R., Jackson, P. R., \& Jaspersen, L. J. (2018). Management and business research. Sage.

Ernst \& Young (2016-2017). Transfer Pricing Survey. Available at: https://www.ey.com/gl/en/services/tax/ey-2016-transferpricing-survey-series (accessed 28 Dec 2018).

Etikan, I. \& Bala, K. (2017). Sampling and sampling methods. Biometrics \& Biostatistics International Journal, $5(6), 149$. Available at: DOI: 10.15406/bbij.2017.05.00149.

Hanlon, B., \& Larget, B. (2011). Samples and Populations. Department of Statistics University of Wisconsin-Madison.

Heinemann, F., \& Janeba, E. (2011). Viewing tax policy through party-colored glasses: What German politicians believe. German Economic Review, 12, 286-311.

Horngren, C. T., Datar, M. S., \& Foster, G. (2003). Cost accounting - a managerial emphasis. New Jersey: Prentice Hall.

Horst, T. (1971). The theory of the multinational firm: Optimal behavior under different tariff and tax rates. Journal of Political Economy 79(5), 1059-1072.

Hung, L. (2017). What is best solution to FDI with transfer pricing activities?. Available at http://vietnamfinance.vn/loi-giainao-hop-ly-voi-doanh-nghiep-fdi-chuyen-gia-20171226115216343.htm (accessed 27 Jul 2018).

Jatnika, R. (2015). The effect of SPSS course to students attitudes toward statistics and achievement in statistics. International Journal of Information and Education Technology, 5(11), IACSIT Press.

Krejcie, R.V., \& Morgan, D.W. (1970). Determining sample size for research activities. Educational and Psychological Measurement, 30, 607-610.

Kumar, A., Schmeler, M. R., Karmarkar, A. M., Collins, D. M., Cooper, R., Cooper, R. A., ... \& Holm, M. B. (2013). Testretest reliability of the functional mobility assessment (FMA): a pilot study. Disability and Rehabilitation: Assistive Technology, 8(3), 213-219.

Lall, S. (1973). Transfer pricing by multinational manufacturing firms. Oxford Bulletin of Economics and Statistics, 35(3), 173-195.

Landy, F. (2006). Vertical integrated enterprises and transfer pricing. Discussion Paper, No. 626, University of Helsinki.

Le, D.D. (2017). Transfer pricing abuse and tax evasion of FDI enterprises will be more complicated. Available at http://vietnamfinance.vn/ts-le-dang-doanh-viec-chuyen-gia-tron-thue-cua-doanh-nghiep-fdi-se-ngay-cang-phuc-tap20171103165324118.htm (accessed 3 Sep 2018).

Lohse, T., \& Riedel, N. (2013). Do transfer pricing laws limit international income shifting? Evidence from European multinationals. Working Papers, Oxford University Centre for Business Taxation no. 13/07. 
Memon, M. A., Ting, H., Ramayah, T., Chuah, F., \& Cheah, J.H. (2017). A review of the methodological misconceptions and guidelines related to the application of structural equation modeling: A Malaysian scenario. Journal of Applied Structural Equation Modeling, 1(1), 1-7.

Ministry of Planning and Investment (2019). Statistics on Foreign Direct Investment in Vietnam 2019. Official Statistics.

Nguyen, H., Tham, J., Khatibi, A \& Azam, S. (2019). Enhancing the capacity of tax authorities and its impact on transfer pricing activities of FDI en-terprises in Ha Noi, Ho Chi Minh, Dong Nai, and Binh Duong province of Vietnam. Management Science Letters, 9(8), 1299-1310.

Nguyen, Q.T. (2012). Tax Control over transfer pricing activities: Current Situation and Solutions. Finance Magazine, March, $10-13$.

Nguyen, V.P. (2015). State control over transfer pricing in Vietnam. PhD Dissertation, Citizen Economics University, Ha Noi.

Organisation for Economic Cooperation and Development, 2010. OECD Transfer Pricing Guidelines for Multinational Enterprises and Tax Administrations 2010. OECD Publishing, Paris. Available at: https://doi.org/10.1787/tpg-2010-en.

Organization for Economic Cooperation and Development (OECD), (2019). OECD expands transfer pricing country profiles to cover 55 countries. Retrieved on https:/www.oecd.org/tax/transfer-pricing/oecd-expands-transfer-pricing-country-profiles-to-cover-55-countries.htm on 5th August 2019.

Phan, T.T.D. (2010). Law on control transfer pricing in Vietnam. PhD Dissertation, University of Law of Ho Chi Minh City.

Quang, L. (2017). Transfer pricing abuse: have to coop with it even how hard it is. Available at http://www.misa.com.vn/tintuc/chi-tiet/newsid/60764/Chong-chuyen-gia-Kho-may-cung-phai-lam (accessed 10 Dec 2018)

Saunders, M., Lewis, P., \& Thornhill, A. (2016). Research methods for business students. Pearson Education Limited, Harlow.

Schjelderup, G. \& Sorgard, L. (1997). Transfer pricing as a strategic device for decentralized Multinationals. International Tax and Public Finance, 4, 277.

See, J.C. (2018). Singapore - Introduction of TP penalties. International Transfer Pricing Journal, 25(5).

Sekaran, U., \& Bougie, R. (2013). Research Methods for Business: A Skill-Building Approach. 6th Edition, Wiley, New York.

Tan, T.L., \& Trang, D.T.D. (2017). Impact Of Transfer Pricing On The National Economy: Situation And Suggestions To Improve Transfer Pricing In Vietnam. National Economics Publishing, Ha Noi.

Thang, N.D. (2015a). Experience in controlling transfer pricing in some countries, lessons for Vietnam. Available at: http://tapchitaichinh.vn/nghien-cuu--trao-doi/trao-doi-binh-luan/kiem-soat-hoat-dong-chuyen-gia-cua-mot-so-nuoc-vabai-hoc-cho-viet-nam-71314.html. (accessed 15 Oct 2018).

Thang, N.D. (2015b). Experience in controlling transfer pricing in some ASEAN countries, lessons for Vietnam. Available at: http://tapchitaichinh.vn/nghien-cuu--trao-doi/trao-doi-binh-luan/chong-chuyen-gia-tai-cac-nuoc-asean-va-bai-hoccho-viet-nam-71713.html. (accessed 15 Oct 2018).

Tham, J., Pambreni, Y., Khatibi, A., \& Azam, S. (2019). The influence of total quality management toward organization performance. Management Science Letters, 9(9), 1397-1406.

Thu, L. (2018). Almost 50\% FDI enterprises report of loss. Available at http://baochinhphu.vn/30-nam-dau-tu-nuoc-ngoaitai-Viet-Nam/Gan-50-doanh-nghiep-FDI-bao-lo-Ke-ho-chuyen-gia/341155.vgp (accessed 29 Aug 2018).

Vietnamese Government (2017). Decree no. 20/2017/ND-CP of the Government dated 24 Feb 2017, effectively from 1 May 2017, on providing tax administration applicable to enterprises engaging in controlled transactions.

Vietnamese Ministry of Finance (2017). Circular no. 41/2017/TT-BTC of the Ministry of Finance of the Government dated 28 Apr 2017, on guiding the implementation of a number of articles of the Government's Decree No. 20/2017/ND-CP of the Government dated $24 \mathrm{Feb} 2017$ on providing tax administration applicable to enterprises engaging in controlled transactions.

Vietnamese National Assembly (2014). Investment Law dated 26 Nov 2014, effective from 1 Jul 2015.

Wadgave, U. \& Khairnar, M. R. (2016). Parametric tests for Likert scale: For and against. Asian Journal of Psychiatry, 24(August), 67-68.

Walliman, N. (2017). Research Methods: The Basics. $2^{\text {nd }}$ Edition, Routledge.

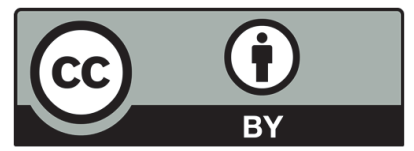

(C) 2020 by the authors; licensee Growing Science, Canada. This is an open access article distributed under the terms and conditions of the Creative Commons Attribution (CC-BY) license (http://creativecommons.org/licenses/by/4.0/). 